(BASDAI 50), and Ankylosing Spondylitis Disease Activity Score (ASDAS) inactive disease and major improvement (Table 1). Response rates at W16 among IV GLM-treated pts were generally consistent through 1 year in both ED and LD subgroups; also in ED and LD subgroups, pts crossing over to IV GLM at W16 demonstrated response at W52 consistent with pts who started IV GLM at W0. At W16, improvements in enthesitis score were similar for pts with ED (mean change -2.9 for IV GLM vs 0.1 for PBO) and LD (mean change -2.5 for IV GLM vs 0.6 for PBO); improvements were maintained at W52 for ED and LD pts. Treatment-emergent adverse events and serious adverse events through 1 year were $46 \%$ and $3 \%$ for pts with ED compared with $61 \%$ and $2 \%$ for pts with LD, respectively.

Conclusion: While IV GLM provided clinically meaningful improvements in signs and symptoms of AS in pts regardless of disease duration, response generally appeared numerically better in pts with ED than in pts with LD. This supports the principle of prompt diagnosis and early treatment.

REFERENCES:

[1] Deodhar A, et al. J Rheumatol. 2018;45:341-348.

[2] Reveille J, et al. J Rheumatol. 2019;46:1277-1283.

Table 1. Efficacy Outcomes

\begin{tabular}{|c|c|c|c|c|c|c|c|c|}
\hline & \multicolumn{4}{|c|}{ ED } & \multicolumn{4}{|c|}{ LD } \\
\hline & \multicolumn{2}{|c|}{ Week 16} & \multicolumn{2}{|c|}{ Week 52} & \multicolumn{2}{|c|}{ Week 16} & \multicolumn{2}{|c|}{ Week 52} \\
\hline & $\begin{array}{l}\text { PBO } \\
(n=25)\end{array}$ & $\begin{array}{c}\text { IV } \\
\text { GLM } \\
(n=35)\end{array}$ & $\begin{array}{c}\text { PBO } \rightarrow \text { IV } \\
\text { GLM } \\
(n=25)\end{array}$ & 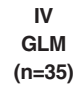 & $\begin{array}{l}\text { PBO } \\
(n=28)\end{array}$ & $\begin{array}{c}\text { IV } \\
\text { GLM } \\
(n=24)\end{array}$ & $\begin{array}{c}\mathrm{PBO} \rightarrow \mathrm{IV} \\
\text { GLM } \\
(\mathrm{n}=28)\end{array}$ & $\begin{array}{c}\text { IV } \\
\text { GLM } \\
(n=24)\end{array}$ \\
\hline ASAS 20 & $32 \%$ & $71 \%$ & $68 \%$ & $71 \%$ & $21 \%$ & $67 \%$ & $68 \%$ & $63 \%$ \\
\hline ASAS 40 & $12 \%$ & $46 \%$ & $56 \%$ & $60 \%$ & $4 \%$ & $42 \%$ & $57 \%$ & $42 \%$ \\
\hline BASDAI 50 & $12 \%$ & $40 \%$ & $64 \%$ & $60 \%$ & $7 \%$ & $33 \%$ & $57 \%$ & $42 \%$ \\
\hline $\begin{array}{l}\text { ASDAS inactive } \\
\text { disease (score } \\
<1.3 \text { ) }\end{array}$ & $4 \%$ & $17 \%$ & $44 \%$ & $37 \%$ & $0 \%$ & $8 \%$ & $14 \%$ & $4 \%$ \\
\hline $\begin{array}{l}\text { ASDAS major } \\
\text { improvement }\end{array}$ & $n=24$ & $57 \%$ & $n=24$ & $51 \%$ & $0 \%$ & $\mathrm{n}=23$ & $46 \%$ & $n=23$ \\
\hline (decrease $\geq 2.0$ ) & $4 \%$ & & $54 \%$ & & & $48 \%$ & & $30 \%$ \\
\hline $\begin{array}{l}\text { ASDAS clinically } \\
\text { important }\end{array}$ & $n=24$ & $77 \%$ & $n=24$ & $77 \%$ & $18 \%$ & $\mathrm{n}=23$ & $61 \%$ & $n=23$ \\
\hline $\begin{array}{l}\text { improvement } \\
\text { (decrease } \geq 1.1 \text { ) }\end{array}$ & $29 \%$ & & $75 \%$ & & & $91 \%$ & & $65 \%$ \\
\hline Mean change from & $\mathrm{n}=23$ & -2.3 & $n=23$ & -2.8 & $n=27$ & $\mathrm{n}=24$ & $\mathrm{n}=27$ & $n=23$ \\
\hline $\begin{array}{l}\text { baseline (SD) in } \\
\text { BASFI }\end{array}$ & $\begin{array}{l}-0.4 \\
(2.0)\end{array}$ & (2.1) & $\begin{array}{l}-2.7 \\
(2.7)\end{array}$ & (2.6) & $\begin{array}{l}-0.3 \\
(1.8)\end{array}$ & $\begin{array}{l}-2.2 \\
(1.7)\end{array}$ & $\begin{array}{l}-2.4 \\
(2.2)\end{array}$ & $\begin{array}{l}-2.3 \\
(1.7)\end{array}$ \\
\hline Mean change from & $\mathrm{n}=23$ & -0.4 & $n=23$ & -0.3 & $\mathrm{n}=27$ & $\mathrm{n}=21$ & $\mathrm{n}=27$ & $n=20$ \\
\hline $\begin{array}{l}\text { baseline (SD) in } \\
\text { BASMI }\end{array}$ & $\begin{array}{l}-0.3 \\
(0.7)\end{array}$ & $(0.7)$ & $\begin{array}{l}-0.6 \\
(0.7)\end{array}$ & $(0.5)$ & $\begin{array}{l}0.01 \\
(0.5)\end{array}$ & $\begin{array}{l}-0.3 \\
(0.6)\end{array}$ & $\begin{array}{l}-0.4 \\
(0.7)\end{array}$ & $\begin{array}{l}-0.3 \\
(0.7)\end{array}$ \\
\hline Mean change from & $n=23$ & -2.9 & $n=23$ & -3.2 & $\mathrm{n}=27$ & $\mathrm{n}=21$ & $\mathrm{n}=27$ & $n=20$ \\
\hline $\begin{array}{l}\text { baseline (SD) in } \\
\text { enthesitis score }\end{array}$ & $\begin{array}{c}0.1 \\
(3.6)\end{array}$ & (2.9) & $\begin{array}{l}-2.0 \\
(4.4)\end{array}$ & (2.5) & $\begin{array}{l}-0.6 \\
(3.4)\end{array}$ & $\begin{array}{l}-2.5 \\
(3.0)\end{array}$ & $\begin{array}{l}-2.5 \\
(3.1)\end{array}$ & $\begin{array}{l}-3.5 \\
(5.9)\end{array}$ \\
\hline
\end{tabular}

$\mathrm{SD}=$ standard deviation

Disclosure of Interests: Atul Deodhar Speakers bureau: AbbVie, Eli Lilly, Janssen, Novartis, Pfizer, UCB, Consultant of: AbbVie, Amgen, Boehringer Ingelheim, Bristol Myers Squibb, Celgene, Eli Lilly, Galapagos, GlaxoSmithKline, Janssen, Novartis, Pfizer, and UCB, Grant/research support from: AbbVie, Eli Lilly, GlaxoSmithKline, Novartis, Pfizer, and UCB, Shelly Kafka Shareholder of: Johnson \& Johnson, Employee of: Janssen Research \& Development, LLC, Elizabeth C Hsia Shareholder of: Johnson \& Johnson, Employee of: Janssen Research \& Development, LLC, Kim Hung Lo Shareholder of: Johnson \& Johnson, Employee of: Janssen Research \& Development, LLC, Lilianne Kim Shareholder of: Johnson \& Johnson, Employee of: Janssen Research \& Development, LLC, Stephen Xu Shareholder of: Johnson \& Johnson, Employee of: Janssen Research \& Development, LLC, John D Reveille Consultant of: Eli Lilly and UCB, Grant/research support from: Eli Lilly and Janssen

DOI: 10.1136/annrheumdis-2021-eular.220

\section{POS0903 CLINICAL AND RADIOLOGICAL MANIFESTATIONS OF COXITIS IN PATIENTS WITH ANKYLOSING SPONDYLITIS (AS) TREATED WITH TNF-ALPHA INHIBITOR GOLIMUMAB: RESULTS OF A 24-MONTHS OBSERVATION (GO-COX STUDY)}

S. Erdes ${ }^{1}$, E. Agafonova ${ }^{1}$, D. Rumiantceva ${ }^{1}$, S. Davidian ${ }^{2}$, E. Zemerova ${ }^{3}$, A. Kulikov ${ }^{4}$, O. Markova ${ }^{5}$, E. Lukyanova ${ }^{6}$, V. Achikyan ${ }^{6} .{ }^{1}$ Federal Rheumatology Research Institute n.a. V.A.Nasonova, Laboratory of Spondyloarthritis and Psoriatic Arthritis, Moscow, Russian Federation; ${ }^{2}$ National Medical and Surgical Center named after N.I. Pirogov, Rheumatology, Moscow, Russian Federation; ${ }^{3}$ Khanty-Mansiysk Autonomous Region - Yugra Regional Clinical Hospital, Rheumatology, Khanty-Mansiysk, Russian Federation; ${ }^{4}$ Rostov-on-Don
Regional Clinical Hospital \#2, Rheumatology, Rostov-on-Don, Russian Federation; ${ }^{5}$ Yakutsk Clinic Lotos, Rheumatology, Yakutsk, Russian Federation; ${ }^{6}$ MSD Pharmaceuticals LLC, Medical Affairs, Moscow, Russian Federation

Background: Coxitis (hip joint inflammation) in AS is associated with worse BASFI scores due to hip joint involvement and more severe axial disease [1] Radiological index of BASRI-hip, US and MRI findings may be used for evaluation of hip joint impairment [2,3,4]. Number of studies on coxitis in AS patients treated with biologics was limited at time of this study initiation.

Objectives: To evaluate clinical changes measured by BASFI, BASMI, BASDAI, ASDAS-CRP and radiological changes in AS patients with coxitis (BASRI-hip hip MRI [STIR- and T1-weighted sequences], hip US) after 12 and 24 months of treatment with TNF alpha inhibitor golimumab from baseline.

Methods: A non-interventional prospective cohort study. Bio-naïve patients with AS and coxitis were treated with golimumab according to daily clinical practice in 5 clinics across Russia and followed up for 24 months. 39 patients participated. This analysis includes data from 30 patients who completed the follow up. The whole cohort's data to be presented after consolidation of safety data. MRI and US data were collected for 12 months in up to 28 of 30 patients. The primary endpoint was mean change of BASFI which was expected to be $-2.5( \pm 2.12)$ from baseline at week 52 weeks (12 months) of therapy [5]. The power of the study was $90 \%$ with minimum sample size of 18 patients. Student's paired t-criteria, Wilcoxon signed rank test were used to compare quantitave and Chi-square test for qualitative variables.

Results: Majority of participants $(66,7 \% ; 20$ out of 30$)$ were male, with mean (SD) age of 33.2 (9.4) years, mean (SD) duration of AS was 36.2 (42.1) months, mean (SD) duration of coxitis was 36.9 (44.1) months. Baseline mean (SD) scores were: BASFI 3.9 (2.5), BASMI 3.1 (2.5), BASDAI 4.9 (2.0), ASDAS-CRP 3.5 (1.2). Changes of mean clinical scores from baseline after 12 and 24 months of treatment with golimumab were: $\triangle B A S F I=-2.2(p=0.0001),-2.1 \quad(p=0.0000)$; $\triangle \mathrm{BASMl}=-1.5(\mathrm{p}=0.0000),-1,8 \quad(\mathrm{p}=0.0000) ; \Delta \mathrm{BASDAl}=-3.0(\mathrm{p}=0.0000),-3.1$ $(p=0.0000) ; \triangle A S D A S-C R P=-2.0 \quad(p=0.0000),-2.1 \quad(p=0.0000)$, correspondingly $(n=30)$. The clinical results (medians, interquartile ranges, min and max) are presented below.

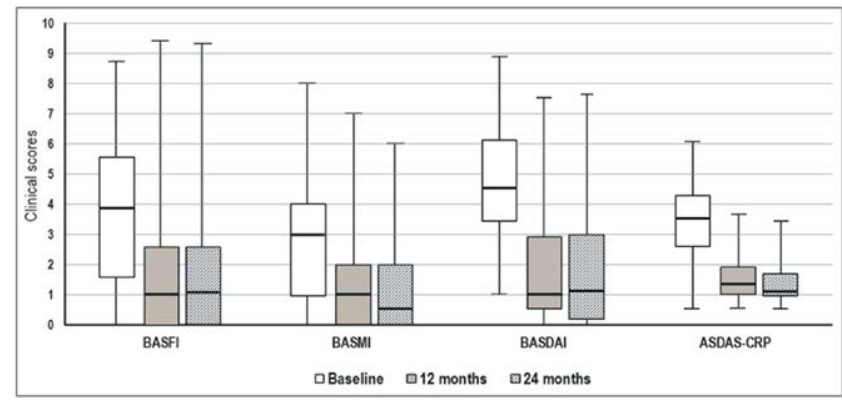

Baseline mean (SD)/median BASRI-hip was $1.1(0.8) / 1.0$ on the right and on the left. Changes of mean/median BASRI-hip score at 12 and 24 months compared to baseline were: $0.3 / 0.0(n=25 ; p=0.2344)$ and $0.3 / 0.0(n=25 ; p=0.1368)$ on the right; $0.4 / 0.0(n=25 ; p=0.0352)$ and $0.4 / 1.0(n=25 ; p=0.0735)$ on the left. Rates of patients with $\mathrm{MRI}$ and US findings are presented below.

\begin{tabular}{lcccc}
\hline Hip MRI, paired analysis & \multicolumn{2}{c}{ Patients (\%), $\mathrm{n}=27$} & \multicolumn{2}{c}{ Patients (\%), $\mathrm{n}=23$} \\
\cline { 2 - 5 } & Baseline & At 6 months & Baseline & At 12 months \\
\hline Right No findings & 33.3 & 48.1 & 39.1 & 56.5 \\
Subchondral bone marrow & 37.0 & 11.1 & 34.8 & 8.7 \\
$\quad$ edema (SBME) & & & & \\
Joint effusion & 74.1 & $25.9^{*}$ & 73.9 & $17.4^{*}$ \\
Enthesitis & 33.3 & 11.1 & 34.8 & 21.7 \\
Fatty degeneration & 37.0 & 55.6 & 34.8 & 52.2 \\
Left & 29.6 & 51.9 & 30.4 & 52.2 \\
No findings & 18.5 & 3.7 & 8.7 & 4.3 \\
SBME & 63.0 & $22.2^{*}$ & 60.9 & 21.7 \\
Joint effusion & 22.2 & 18.5 & 17.4 & 21.7 \\
Enthesitis & 33.3 & 55.6 & 30.4 & 52.2 \\
Fatty degeneration & Patients $(\%), \mathrm{n}=28$ & Patients (\%), $\mathrm{n}=27$ \\
US, paired analysis & Baseline & At 6 months & Baseline & At 12 months \\
Hip & 14.3 & $50.0^{*}$ & 18.5 & $51.9^{*}$ \\
Right No findings & 46.4 & 25.0 & 51.9 & $11.1^{*}$ \\
Joint effusion & 25.0 & 14.3 & 18.5 & 14.8 \\
Enthesitis & 14.3 & $50.0^{*}$ & 18.5 & $55.6^{*}$ \\
Left & 42.9 & 28.6 & 48.1 & 25.9 \\
No findings & 17.9 & 17.9 & 11.1 & 18.5 \\
Joint effusion & & & & \\
Enthesitis & & & & \\
\hline
\end{tabular}

${ }^{*} p<0.05$ 
Conclusion: Therapy with TNF alpha inhibitor golimumab for 24 months in AS patients with coxitis was accompanied with statistically significant improvement of clinical scores with primary endpoint achieved (mean BASFI change -2.5 at 12 months), improvement of MRI and US findings without obvious structural progression measured with BASRI-hip score compared to baseline.

REFERENCES:

[1] Cruyssen B.V. et al. Rheumatology 2010; 49: 73-81.

[2] Boonen A. et al. J Rheumatol 2009; 36; 1249-1255.

[3] Cruyssen B.V. et al. Curr Opin Rheumatol 2013, 25: 448-454.

[4] Zhen-Guo H. et al. European Journal of Radiology 82 (2013) 1487-1493.

[5] Konsta et al. Clin Rheumatol (2013) 32:1229-1232.Braun J. et al. Ann Rheum Dis 2012; 71: 661-667.

Disclosure of Interests: Shandor Erdes Speakers bureau: Paid as a speaker during educational activities supported by pharmaceutical companies (MSD, Pfizer, AbbVie, BIOCAD), Ekaterina Agafonova Speakers bureau: Paid as a speaker during educational activities supported by pharmaceutical companies (MSD)., Daria Rumiantceva Speakers bureau: Paid as a speaker during educational activities supported by pharmaceutical companies (Novartis), Satenik Davidian: None declared, Elena Zemerova Speakers bureau: Paid as a speaker during educational activities supported by pharmaceutical companies (MSD, Pfizer), Aleksey Kulikov Speakers bureau: Paid as a speaker during educational activities supported by pharmaceutical companies (MSD, AbbVie, UCB, BIOCAD, Novartis, Sanofi), Olga Markova Speakers bureau: Paid as a speaker during educational activities supported by pharmaceutical companies (MSD, Novartis, Medac, GSK), Ekaterina Lukyanova Employee of: MSD Pharmaceutical LLC (Russia), Director of Medical Affairs., Vladimir Achikyan Employee of: MSD Pharmaceutical LLC (Russia), Therapeutic Area Lead

DOI: 10.1136/annrheumdis-2021-eular.299

\section{POS0904 FACTORS ASSOCIATED WITH SWITCHING FROM ONE ANTI-TNF AGENT TO ANOTHER ANTI-TNF, OR IL17 AGENT IN PATIENT WITH ANKYLOSING SPONDYLITIS}

M. Hwang ${ }^{1}$, M. Weisman ${ }^{2}$, L. S. Gensler ${ }^{3}$, A. Tahanan ${ }^{4}$, M. Ishimori ${ }^{2}$, T. Hunter ${ }^{5}$ R. Bolce ${ }^{5}$, J. Lisse ${ }^{5}$, M. Rahbar6, M. Shan ${ }^{5}$, J. D. Reveille ${ }^{7}{ }^{1}$ McGovern Medical School at UTHealth, Rheumatology, Houston, United States of America;

${ }^{2}$ Cedars-Sinai Medical Records Office, Rheumatology, Los Angeles, United States of America; ${ }^{3}$ University of California San Francisco Parnassus Campus, Rheumatology, San Francisco, United States of America; ${ }^{4}$ University Of Texas Professional Building, Medicine, Houston, United States of America; ${ }^{5}$ Eli Lilly, Medical Affairs, Indianapolis, United States of America; ${ }^{4}$ University Of Texas Professional Building, Medicine, Houston, United States of America; ${ }^{7}$ University of Texas McGovern Medical School, Rheumatology, Houston, United States of America

Background: A recent study examining Commercial Claims Insurance database found that many patients with ankylosing spondylitis (AS) do not remain on their initial TNF inhibitor two years after initiation, particularly women and those taking opioids.

Objectives: To examine factors associated with switching from one TNF inhibitor (i)agent to either another TNFi, IL-17i or JAKi over time (at <2years and >2 years) in a longitudinal cohort of AS patients.

Methods: Patients enrolled in the Prospective Study of Outcomes in AS (PSOAS), an observational longitudinal study of predictors of AS severity operative since 2002-2020 including over 1250 patients meeting modified New York criteria. Data collected included age, gender, ethnicity, HLA-B27 status, disease activity (BASDAI or ASDAS), erythocyte sedimentation rate (ESR), C-reactive protein (CRP), disease severity,(functional (BASFI) or radiographic (mSASSS)), comorbidities, smoking, exercise, disease duration, depression (either by self report or by the Center for Epidemiologic Studies Depression Scale (CES-D) and other medication usage (NSAIDs, including the NSAID index, nonbiologic DMARDs, opioids, anti-depressants, anxiolytics and hypnotics). Logistic regression models were built to identify clinical and sociodemographic characterstics associated with medication switching to another TNFi, IL-17i, or other biologic therapy (another TNFi, II-17i, or JAKi) within 2 years and after 2 years of initiation).

Results: Of those patients in PSOAS who had at least two years of follow-up, 496 were prescribed anti-TNF, 34 anti-IL-17 and 3 anti-JAK agents. According to the multinomial logistic regression analysis, patients who switched from their original TNFito another TNFi, IL-17i or JAKi within two years after initiating their original TNFi were more likely to be older, have higher baseline subjective disease activity (BASDAI), less radiographic severity by MSASSS, exercise $>120$ minutes/week and less likely to be currently smoking. Patients who switched after two years were less likely be depressed, had shorter disease duration, had greater subjective disease activity, were more likely to be exercising $>120 \mathrm{~min}$ utes/week, and had more comorbidities.

Conclusion: Different factors were encountered in AS patients who switched from their initial TNFi to another TNFi, IL-17i or JAKi within 2 years versus after 2 years of treatment.
Table 1. Factors Associated With Switching From One TNFi To A Second TNFi or IL-17i or JAKi Before or After Two Years Based On Multinomial Logistic Regression Model (N=496 Patients)

\begin{tabular}{|c|c|c|c|c|}
\hline Variable & $\begin{array}{l}\text { Switched within } \\
2 \text { years vs. not } \\
\text { switched }\end{array}$ & p-value & $\begin{array}{l}\text { Switched after } \\
2 \text { years vs. not } \\
\text { switched }\end{array}$ & p-value* \\
\hline Gender (Male vs. Female) & $\begin{array}{c}0.99 \\
(0.637,1.549)\end{array}$ & 0.98 & $\begin{array}{c}0.95 \\
(0.528,1.719)\end{array}$ & 0.87 \\
\hline HLA-B27_(+ vs. -) & $\begin{array}{c}0.99 \\
(0.639,1.523)\end{array}$ & 0.95 & $\begin{array}{c}0.66 \\
(0.365,1.192)\end{array}$ & 0.17 \\
\hline $\begin{array}{l}\text { Depression (CESD } \geq 16 \text { or } \\
\text { self-report)(Yes vs. No) }\end{array}$ & $\begin{array}{c}0.99 \\
(0.676,1.445)\end{array}$ & 0.95 & $\begin{array}{c}0.35 \\
(0.182,0.672)\end{array}$ & 0.002 \\
\hline $\begin{array}{l}\text { Disease duration at baseline } \\
\text { ( } \geq 20 \text { vs. }<20 \text { years) }\end{array}$ & $\begin{array}{c}0.72 \\
(0.485,1.062)\end{array}$ & 0.10 & $\begin{array}{c}0.27 \\
(0.146,0.491)\end{array}$ & $<0.001$ \\
\hline $\begin{array}{l}\text { Age at baseline ( } \geq 40 \text { vs. }<40) \\
\quad \text { (years) }\end{array}$ & $\begin{array}{c}2.00 \\
(1.291,3.101)\end{array}$ & 0.002 & $\begin{array}{c}1.23 \\
(0.693,2.193)\end{array}$ & 0.48 \\
\hline CRP ( $\geq 0.8$ vs. $<0.8$ ) & $\begin{array}{c}1.94 \\
(1.230,3.056)\end{array}$ & 0.004 & $\begin{array}{c}0.90 \\
(0.454,1.789)\end{array}$ & 0.77 \\
\hline BASFI ( $\geq 40$ vs. $<40$ ) & $\begin{array}{c}1.34 \\
0.852,2.118)\end{array}$ & 0.20 & $\begin{array}{c}0.87 \\
(0.450,1.688)\end{array}$ & 0.68 \\
\hline BASDAI ( $\geq 4$ vs. $<4$ ) & $\begin{array}{c}1.73 \\
(1.064,2.797)\end{array}$ & 0.03 & $\begin{array}{c}2.31 \\
(1.202,4.427)\end{array}$ & 0.01 \\
\hline NSAID index ( $\geq 50$ vs. $<50$ ) & $\begin{array}{c}1.32 \\
(0.822,2.128)\end{array}$ & 0.25 & $\begin{array}{c}0.83 \\
(0.437,1.586)\end{array}$ & 0.58 \\
\hline NSAIDs used (Yes vs. No) & $\begin{array}{c}0.84 \\
(0.534,1.309)\end{array}$ & 0.43 & $\begin{array}{c}0.85 \\
(0.479,1.510)\end{array}$ & 0.58 \\
\hline $\begin{array}{l}\text { Exercise ( } \geq 120 \text { vs. }<120) \\
\quad \text { (minutes/week) }\end{array}$ & $\begin{array}{c}1.95 \\
(1.396,2.731)\end{array}$ & $<0.001$ & $\begin{array}{c}1.66 \\
(1.057,2.613)\end{array}$ & 0.03 \\
\hline ASDAS ( $\geq 3$ vs. $<3$ ) & $\begin{array}{c}0.78 \\
(0.454,1.356)\end{array}$ & 0.39 & $\begin{array}{c}1.07 \\
(0.478,2.399)\end{array}$ & 0.87 \\
\hline $\begin{array}{l}\text { Number of comorbidities } \\
\qquad(\geq 2 \text { vs. }<2)\end{array}$ & $\begin{array}{c}1.40 \\
(0.997,1.951)\end{array}$ & 0.05 & $\begin{array}{c}1.63 \\
(1.029,2.575)\end{array}$ & 0.04 \\
\hline mSASSS ( $\geq 4$, vs. $<4$ ) & $\begin{array}{c}0.63 \\
(0.421,0.957)\end{array}$ & 0.03 & $\begin{array}{c}0.81 \\
(0.474,1.392)\end{array}$ & 0.03 \\
\hline Current smoker (Yes vs No) & $\begin{array}{c}0.69 \\
(0.385,1.225)\end{array}$ & $<0.001$ & $\begin{array}{c}0.79 \\
(0.297,2.076)\end{array}$ & 0.20 \\
\hline
\end{tabular}

*p-values calculated based on multinomial logistic regression model when switching is defined as being prescribed a second TNFi or taking IL-17i or JAKi before or after 2 years from first TNFi initiation

Disclosure of Interests: Mark Hwang Consultant of: UCB, Novartis, Michael Weisman Consultant of: Novartis, GSK, UCB, Lilly, Lianne S. Gensler Consultant of: AbbVie, GlaxoSmithKline, Eli Lilly, Novartis, Pfizer, UCB Pharma, Amirali Tahanan: None declared, Mariko Ishimori: None declared, Theresa Hunter Employee of: Eli Lilly, Rebecca Bolce Employee of: Eli Lilly, Jeffrey Lisse Employee of: Eli Lilly, Mohammad Rahbar: None declared, Minyang Shan Employee of: El Lilly, John D Reveille Consultant of: UCB, Grant/research support from: Eli Lilly DOI: 10.1136/annrheumdis-2021-eular.515

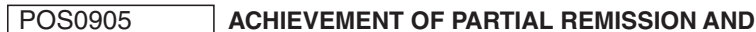 INACTIVE DISEASE IN UPADACITINIB-TREATED PATIENTS WITH ANKYLOSING SPONDYLITIS}

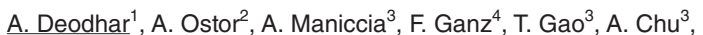

D. Poddubnyy ${ }^{5} .{ }^{1}$ Oregon Health \& Science University, Rheumatology, Portland, United States of America; ${ }^{2}$ Cabrini Hospital, Monash University \& Emeritus Research, Melbourne, Australia; ${ }^{3}$ AbbVie Inc., Rheumatology, North Chicago, United States of America; ${ }^{4}$ AbbVie, Rheumatology, Baar, Switzerland;

${ }^{5}$ Department of Gastroenterology, Infectious Diseases and Rheumatology, Charité-Universitätsmedizin, and Epidemiology Unit, German Rheumatism Research Centre, Berlin, Germany

Background: Assessment of SpondyloArthritis international Society (ASAS) response criteria and AS Disease Activity Score (ASDAS) are both commonly used, rigorous composite indices consisting of components with relevance to patients. Clinically meaningful thresholds for these measures have been defined to reflect partial remission (PR), inactive disease (ID), and low disease activity (LDA).

Objectives: To study the association of ASAS PR and ordinal ASDAS disease categories (including ASDAS ID, which is the most stringent category of this composite score) in upadacitinib (UPA)-treated patients with AS.

Methods: In the SELECT-AXIS 1 (NCT03178487) study, biologic DMARD naïve-patients (pts; $\geq 18 \mathrm{y}$ ) with active AS and intolerance/contraindication or inadequate response to $\geq 2$ NSAIDs were randomized $1: 1$ to UPA $15 \mathrm{mg}$ once daily (QD) or placebo (PBO). ${ }^{1}$ At wk 14, pts entered an open-label extension (OLE) of UPA $15 \mathrm{mg}$ QD; pts randomized to $\mathrm{PBO}$ were switched to UPA. This post hoc analysis assessed the responsiveness of individual ASAS and ASDAS core components among pts who achieved ASAS PR. The association of ASAS PR with achievement of ASDAS ID (ASDAS <1.3), ASDAS LDA (ASDAS <2.1 but $\geq 1.3$ ) or ASDAS high disease activity (HDA)/very HDA (VHDA) (ASDAS $\geq 2.1$ for HDAVHDA) was also assessed by measures including Youden index, distance to perfect point, and sensitivity/specificity 